\title{
Effect of Gestational Age and Retinol (Vitamin A) Deficiency on Fetal Rat Lung Nuclear Retinoic Acid Receptors
}

\author{
KANDI R. MCMENAMY AND RICHARD D. ZACHMAN \\ Division of Neonatology, Department of Pediatrics [K.R.M., R.D.Z.J, and Nutritional Sciences /R.D.Z./. \\ University of Wisconsin, Madison, Wisconsin 53715
}

\begin{abstract}
Retinol, or one of its metabolites such as retinoic acid (RA), is an important factor in the differentiation and maintenance of integrity of lung epithelium. Retinol deficiency in rats induces morphologic changes in respiratory tract epithelial cells that are histologically similar to those found in human premature infants with bronchopulmonary dysplasia. The exact mechanism of retinoid action in cellular growth and differentiation is not understood, but recently investigators have focused on mechanisms mediated by nuclear RA receptors (RAR). The role of these RAR as regulators of retinoid function is being studied in adult animal tissues and malignant cell lines, but little is known about RAR in developing fetal lung tissue. The purpose of this study was to determine the effect of gestational age and vitamin A deficiency on fetal rat lung nuclear RAR. RAR were also assayed in vitamin A control and vitamin A-deficient adult rat lung. A competitive binding assay and size exclusion HPLC separation were used to quantitate total RAR-specific binding. Binding analysis revealed a single class of receptor binding sites with high affinity $\left(k_{d} \sim 10^{-9} M\right)$ for $R A$ and $R A R$ saturation at 2-5 nM RA. Specific binding of lung RAR in rat fetuses at $18 \mathrm{~d}$ gestation was two to three times greater than in fetuses at 20-21 d gestation, newborn pups, or adults. Western blot analysis revealed a predominance of $\operatorname{RAR}-\beta$ receptors in fetal lung. Lungs from vitamin A-deficient fetuses demonstrated up-regulation of nuclear RAR. Lung RAR-specific binding from adult female rats raised on a vitamin $\mathrm{A}$-deficient diet since they were weanlings was no different from that of vitamin A-supplemented controls. These observations suggest that both gestational age and vitamin $A$ are important regulators of $R A R$ in developing lung. Such regulation might be important as well in the pathogenesis and/or repair of neonatal lung injury. (Pediatr Res 33: 251-255, 1993)
\end{abstract}

\section{Abbreviations}

RA, retinoic acid

RAR, retinoic acid receptor protein

BPD, bronchopulmonary dysplasia

$\mathrm{RP}$, retinyl palmitate

$\mathrm{PI}$, protease inhibitor

Received August 11. 1992: accepted October 26, 1992

Correspondence: Dr Richard D. Zachman, University of Wisconsin-Meriter Perinatal Center, 202 South Park St., Madison, WI 53715.

Supported in part by NHLBI 1-P50-HL 46478-01 (R.D.Z.), Stetler Research Award (K.R.M.) No. 48959, and National Research Service Fellowship Award (K.R.M.) F32-HL08751-01
Retinol, or one of its metabolites such as RA, is an important factor in the differentiation and maintenance of integrity of many epithelial cell types including the epithelial cells lining the respiratory tract. Retinol deficiency in rats is characterized by the loss of ciliated and mucus-producing cells and the replacement of normal columnar epithelia with squamous metaplasia $(1-3)$. These findings are similar to the histologic changes found in the lungs of human premature infants with BPD (4).

In general, vitamin A levels at birth are lower in preterm infants than in term infants (5-7), and preterm infants who subsequently develop BPD often have lower plasma retinol levels than preterm infants who do not develop $\operatorname{BPD}(8,9)$. At present, controlled trials with small numbers of premature infants are inconclusive in regard to whether or not vitamin A supplementation decreases the morbidity associated with BPD $(10,11)$. In any event, the cellular mechanisms by which vitamin $A$ might act in normal lung development or lung injury and repair have not been adequately studied.

Retinol and RA are transported in the plasma bound to retinolbinding protein and albumin, respectively. Once inside the cell, a portion of retinol is irreversibly oxidized to RA, which binds to cytosolic RA-binding protein (12). RA then undergoes other metabolic conversions or is transported to the nucleus, where $\mathrm{RA}$ is the ligand for nuclear RAR. The activated RAR complex is thought to regulate gene expression by interaction with RAresponsive elements located on DNA (12). At least three distinct RAR subtypes $(\alpha, \beta$, and $\gamma)$ have been identified in a variety of adult animal tissues and also in malignant cell lines (13-15). The expression of mRNA for the RAR in early chick and mouse embryo (16) and adult lung (17) is being studied, but the protein level of these potential mediators of retinoid function in fetal or neonatal lung tissue has not been reported.

The purpose of this research was to characterize the nuclear RAR in developing fetal rat lung. The effect of gestational age on developing rat lung RAR was assessed, and the effect of vitamin A deficiency on fetal and adult lung RAR was also studied. A single class of receptor binding sites for fetal rat lung RAR was demonstrated, and total RAR-specific binding was significantly higher in 18-d fetuses than in older fetuses, newborns, or adults. Vitamin A-deficient fetuses demonstrated up-regulation of lung RAR, whereas vitamin A-deficient adults did not.

\section{MATERIALS AND METHODS}

Sprague-Dawley rats were obtained from Harlan SpragueDawley, Madison, WI. They were housed one to two per cage (adults) or three to four per cage (weanlings) in suspended wire cages with individual water and feeders. Light and dark were cycled at 12-h intervals. Vitamin A-deficient diet was obtained from ICN Biochemicals, Cleveland, $\mathrm{OH}$. The use and care of the animals was approved by the Research Animal Resource Center at the University of Wisconsin. All-trans $-\left[{ }^{3} \mathrm{H}\right]-\mathrm{RA}(50 \mathrm{Ci} / \mathrm{mmol})$ 
was obtained from New England Nuclear, Boston, MA. All other chemicals were obtained from Sigma Chemical Co., St. Louis, MO. Gel filtration standards for molecular weight determination were obtained from Bio-Rad, Richmond, CA. Polyclonal antibodies to RAR subtypes were kindly supplied by Dr. Pierre Chambon, Paris, France.

Animals. Timed pregnant Sprague-Dawley rats (term 22 d) were obtained at 17-20 d gestation and the fetuses were delivered at 18-21 d gestation. The dams were anesthetized with ether or intraperitoneal pentobarbital, and the fetuses were delivered by cesarean section and immediately decapitated. Maternal animals were then killed by cardiac excision, and their lungs and livers were collected and frozen separately at $-20^{\circ} \mathrm{C}$ until use. Fetal tissues from each litter were pooled and stored similarly. For some experiments at $18 \mathrm{~d}$ gestation, fetal tissues were pooled from two to three litters to increase yield.

Nuclear RAR assay. Lung nuclei preparation and the RAR competitive binding assay were performed as described by Nervi et al. (15) with a few modifications. Weighed portions of lung $(0.1-1.5 \mathrm{~g})$ were homogenized at $4^{\circ} \mathrm{C}$ with a teflon-glass homogenizer (pestle B, 40-50 strokes) in $5 \mathrm{~mL}$ of PTG buffer $(5 \mathrm{mM}$ sodium phosphate/10 mM thioglycerol/10\% glycerol, $\mathrm{pH} 7.4$ ) and the following PI: phenylmethyl sulfonyl fluoride $(1 \mathrm{mM})$, aprotinin $(1 \mu \mathrm{g} / \mathrm{mL})$, and leupeptin $(1 \mu \mathrm{g} / \mathrm{mL})$. The homogenate was centrifuged at $1000 \times g$ at $4^{\circ} \mathrm{C}$ for $15 \mathrm{~min}$ and the resultant supernatant (cytosolic fraction) was discarded. The nuclear pellet was rewashed with $5 \mathrm{~mL}$ PTG + PI and centrifuged two to three times until the supernatant was clear. The final nuclear pellet was suspended in $1-5 \mathrm{~mL}$ of TTGK buffer $(10 \mathrm{mM}$ Tris $\mathrm{HCl} /$ $1.5 \mathrm{nM}$ EDTA/10 mM thioglycerol/10\% glycerol $/ 0.8 \mathrm{M} \mathrm{KCl}$, $\mathrm{pH}$ 8.5) with the same PI added as in the PTG buffer. The suspension was incubated on ice for $1 \mathrm{~h}$ and resuspended every 10-15 min with a teflon-glass homogenizer (pestle $A$, three to four strokes). The suspension was then centrifuged at $66000 \times$ $g$ for $1 \mathrm{~h}$ and the resultant supernatant saved as the nuclear fraction. Protein concentration of this nuclear preparation was performed by the method of Lowry (18) using BSA as the standard, and aliquots of $100-750 \mu \mathrm{g}$ of protein were stored in 1.5-mL Eppendorf tubes at $-20^{\circ} \mathrm{C}$ until use.

For the nuclear RAR competitive binding assay, $\left[{ }^{3} \mathrm{H}\right]-\mathrm{RA}$ was added to known amounts of nuclear protein for a final concentration of $0.4-10 \mathrm{nM}\left[{ }^{3} \mathrm{H}\right]-\mathrm{RA}$ in the presence or absence of a 200 -fold molar excess of unlabeled RA. The final volume of 400 $\mu \mathrm{L}$ was incubated for $3 \mathrm{~h}$ at $4^{\circ} \mathrm{C}$, then the ligand-receptor complex was separated from other proteins and free RA by size-exclusion HPLC using a Perkin-Elmer (Norwalk, CT) model LC-100 liquid chromatography system. Injections of $200 \mu \mathrm{L}$ were fractionated over a Superose 12 HR 10/30 size exclusion column (Pharmacia, Piscataway, NJ) at a flow rate of $0.5 \mathrm{~mL} / \mathrm{min}$ using PTG buffer containing $0.4 \mathrm{M} \mathrm{KCl}$ and $\mathrm{PI}$ at $4^{\circ} \mathrm{C}$ as eluent. Fractions of 0.5 $\mathrm{mL}$ were collected and radioactivity was measured. Binding data were calculated as the area under the peak using the trapezoidal rule and expressed as $\mathrm{dpm} / \mathrm{mg}$ nuclear protein. Molecular weight was determined by comparison of relative elution times to known molecular weight standards. Western blot analysis was performed on $30 \mu \mathrm{g}$ of protein from HPLC fractions 24-26 using polyclonal antibodies raised against mouse $(1: 1000)$. Goat anti-rabbit was the second antibody, used to perform Western blot analysis, and an alkaline phosphatase color reaction was used to identify the bands.

Vitamin A-deficient animals. Vitamin A-deficient females and offspring were obtained using the method of Wallingford and Underwood (19) with a few modifications. Weanling female Sprague-Dawley rats were fed a vitamin A-deficient diet ad libitum for $8-10 \mathrm{wk}$, then some rats were killed and livers and lungs were collected. Vitamin A deficiency was documented by analysis of liver RP concentration as previously described (20) using a Perkin-Elmer Picosil C18 $5 \mu \mathrm{m}, 15 \mathrm{~cm}$ column. The remaining rats were then mated to normal males, and the presence of vaginal sperm after overnight mating denoted $\mathrm{d} 0$ of pregnancy. On d 0 or 1 of pregnancy, the vitamin A-deficient females were started on 10 retinol equivalents ( 1 retinol equivalent $=1 \mu \mathrm{g}$ retinol $=3.33 \mathrm{IU})$ of $\mathrm{RP} / \mathrm{d}$ to improve pregnancy outcome (19). Daily monitoring revealed that the rats completely ingested the diet with the added vitamins. The rats were killed at 20 or $21 \mathrm{~d}$ gestation, and maternal livers and fetal livers and lungs were collected. Fetal tissues from individual litters were pooled. All tissues were frozen at $-20^{\circ} \mathrm{C}$ until use.

Statistical analysis. Data are expressed as means and SEM as indicated. Differences among group means were determined by unpaired two-tailed $t$ tests, and $p<0.05$ was considered significant. Scatchard plots (21) were analyzed using least squares linear regression.

\section{RESULTS}

$R A R$ assay. A representative competitive binding analysis of 20-d fetal rat lung using $5 \mathrm{nM}$ radiolabeled RA shows multiple peaks of radioactivity (total binding), only one of which (fractions 24-26) is abolished by excessive unlabeled RA (nonspecific binding). This indicates specific binding for the RAR (Fig. 1). Using molecular weight standards, the peak at fraction 25 corresponds to a molecular weight of approximately 50000 . Similar analysis of the cytosolic fraction demonstrated no such peak in this area, indicating that virtually all the nuclear fraction was retained during the preparation of nuclei. Incubation at room temperature versus $4^{\circ} \mathrm{C}$ yielded identical results, as did incubation periods at $4^{\circ} \mathrm{C}$ of $3 \mathrm{~h}$ versus $18 \mathrm{~h}$. Nuclei preparations were stored frozen at $-20^{\circ} \mathrm{C}$ for up to 4 mo without loss of RARspecific binding. RAR-specific binding increased proportionately with increasing amounts of nuclear protein, and repeated measures on the same sample yielded an intraassay variability of $<10 \%$. Western blot analysis of the peak of specific binding (fractions 24-26) from fetal and neonatal lung showed predominantly RAR- $\beta$ with a trace of RAR- $\alpha$ when studied with polyclonal mouse antibodies (Fig. 2).

Effect of gestational age. Figure 3 illustrates saturation binding of lung RAR of rat fetuses at 18-21 d gestation. Optimal binding occurred at concentrations of radiolabeled ligand greater than 2 $\mathrm{nM}$ in 19- to $21-\mathrm{d}$ fetal rat lung, but 18 -d fetal rat lung RAR did not show saturation until higher concentrations of RA were reached (5 nM). Scatchard analysis (Fig. 4) yielded linear plots consistent with the presence of a single class of receptor binding sites. The apparent equilibrium $\mathrm{k}_{d}$ ranged from $0.77 \mathrm{nM}(r=$ $-0.99)$ for $21-\mathrm{d}$ and $0.97 \mathrm{nM}(r=-0.88)$ for 20 -d fetal rat lung to $1.75 \mathrm{nM}(r=-0.97)$ for $18-\mathrm{d}$ and $2.68 \mathrm{nM}(r=-0.67)$ for

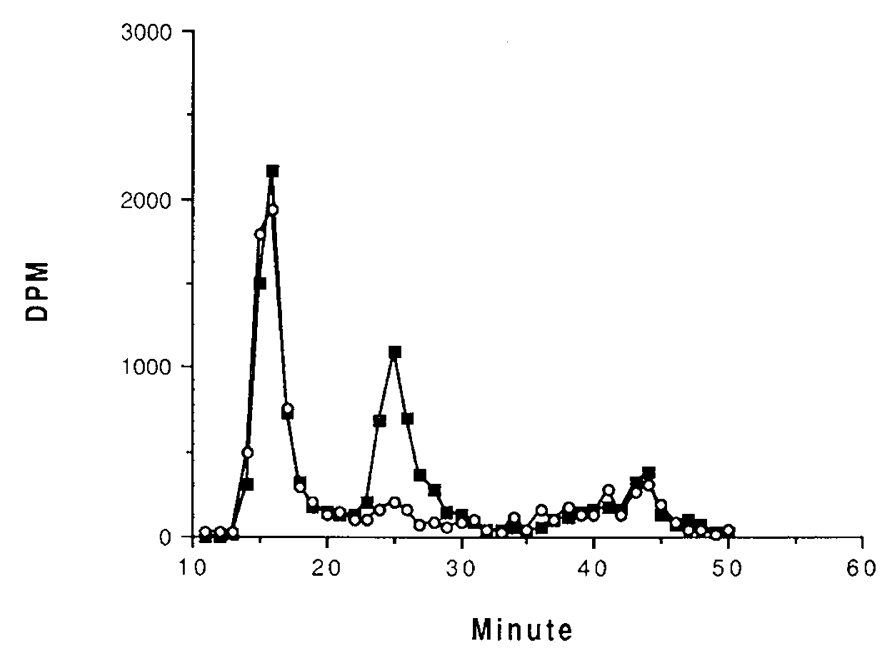

Fig. 1. Competitive binding analysis of HPLC-separated RAR assay. The dpm in each minute $(0.5 \mathrm{~mL})$ for $\left[{ }^{3} \mathrm{H}\right]$-RA only (total binding, and $\left[{ }^{3} \mathrm{H}\right]-\mathrm{RA}$ plus 200 -fold molar excess of unlabeled RA (nonspecific binding, $O$ ) are shown. 

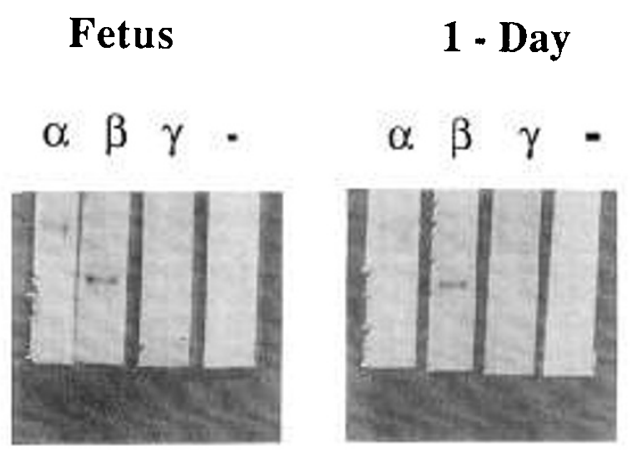

$-66.2 \mathrm{kD}$

$-50.0 \mathrm{kD}$

$-42.7 \mathrm{kD}$

$-31.0 \mathrm{kD}$

Fig. 2. Western blot analysis of RAR peak. Fetal and 1-d-old rat nuclear extracts from HPLC fractions 24-26 were desalted, concentrated, and subjected to Western blot analysis against polyclonal antibody.

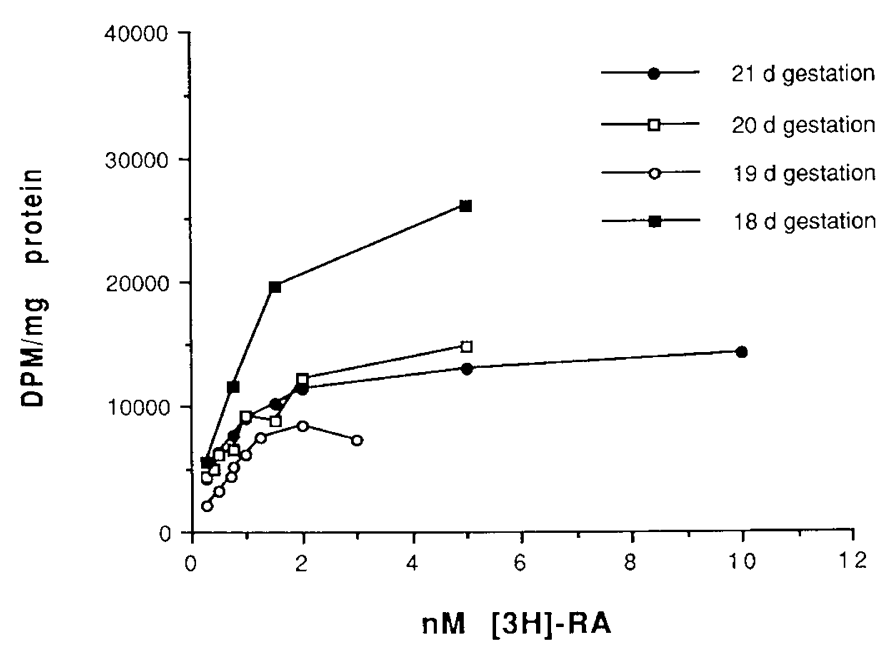

Fig. 3. Saturation binding of RAR. Specific binding (total binding minus nonspecific binding) is plotted against increasing $\left[{ }^{3} \mathrm{H}\right]-\mathrm{RA}$ concentration for various gestational ages.

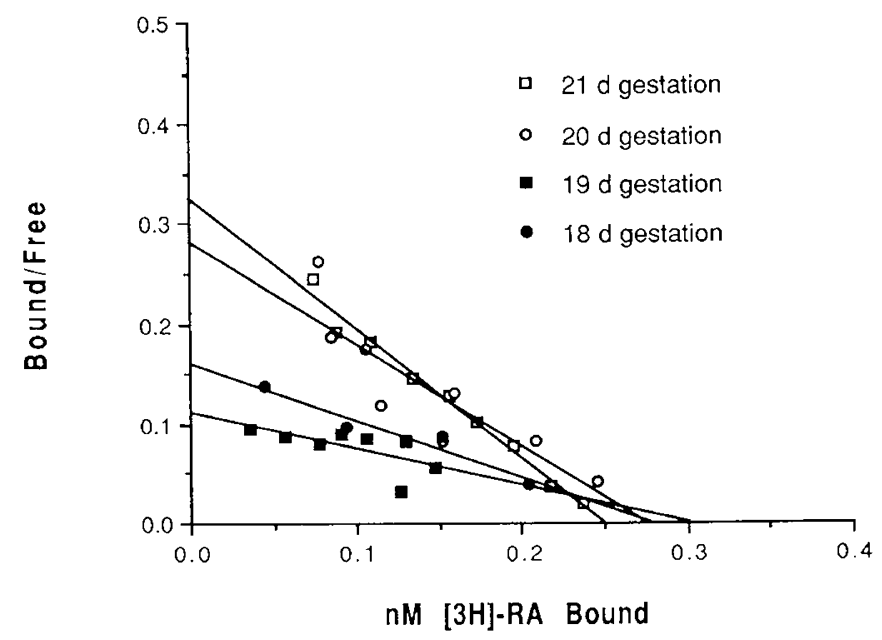

Fig. 4. Scatchard analysis. Scatchard analysis of saturation binding at various gestational ages.

19-d fetal rat lung. Total RAR-specific binding (expressed as $\mathrm{dpm} / \mathrm{mg}$ nuclear protein) in lungs from various fetal and postnatal aged rats incubated with saturating concentrations of RA $(5 \mathrm{nM})$ is shown in Figure 5. Lungs from 18-d fetal rats $(n=4)$ contained two to three times as much RAR-specific binding (25 $966 \pm 5140 \mathrm{dpm} / \mathrm{mg}$ protein) as 20 - to 21 -d fetuses (11 980 $\pm 672 \mathrm{dpm} / \mathrm{mg}$ protein, $n=7, p<0.01$ ), 1 - to 3 -d-old newborn pups $(9698 \pm 3992 \mathrm{dpm} / \mathrm{mg}$ protein, $n=4, p<0.05)$, and

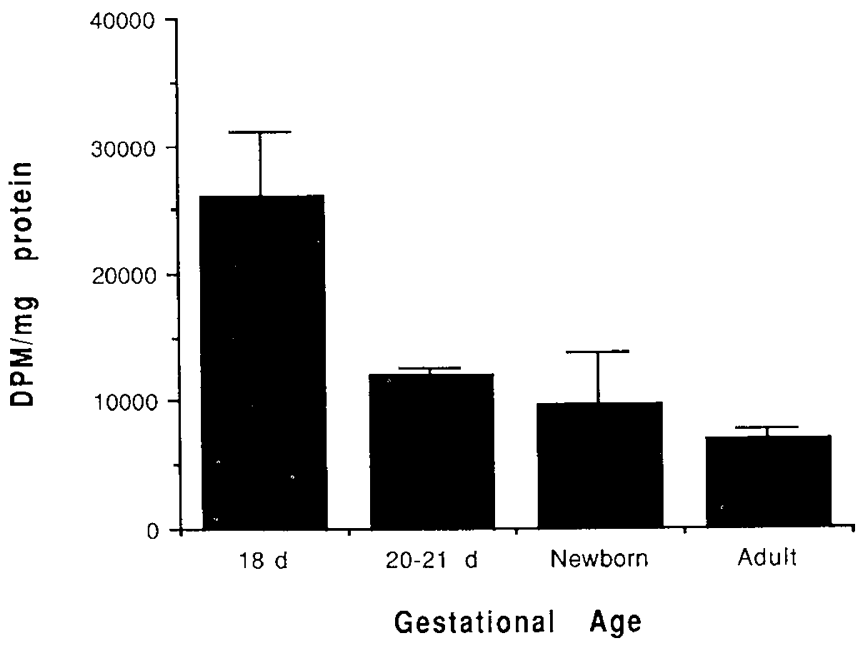

Fig. 5. Total RAR-specific binding in fetal and postnatal aged rats. $\mathrm{Dpm} / \mathrm{mg}$ nuclear protein was plotted against the gestational ages indicated.

adult pregnant females (7 $042 \pm 772 \mathrm{dpm} / \mathrm{mg}$ protein, $n=6, p$ $<0.01$ ).

Effect of vitamin A deficiency. Timed-pregnant Sprague-Dawley rats consuming regular rat food were used as a reference control group and compared with pregnant, vitamin A-deficient rats (Table 1). Vitamin A-deficient diet resulted in markedly reduced maternal liver RP concentration compared with normal diet $(46 \pm 12$ versus $866 \pm 224 \mathrm{nmol} \mathrm{RP} / \mathrm{g}$ liver, respectively). This concentration of liver RP in vitamin A-deficient maternal rats at 20-21 d gestation ( $46 \pm 12 \mathrm{nmol} \mathrm{RP} / \mathrm{g}$ liver) was higher than baseline concentrations obtained before mating $(2.9 \pm 1.1$ $\mathrm{nmol} \mathrm{RP} / \mathrm{g}$ liver) due to the vitamin A supplement received by these rats during their pregnancy. Vitamin $\mathrm{A}$-deficient animals had a smaller litter size $(p<0.001)$ and a smaller average fetal weight $(p<0.02)$ than the reference group. Fetal liver RP concentration was significantly lower in deficient pregnancies $(p$ $<0.001$ ) (Table 1). Lung RAR-specific binding of vitamin Adeficient fetuses was increased by 2 -fold over that of controls $(23560 \pm 1792$ versus $11980 \pm 672 \mathrm{dpm} / \mathrm{mg}$ protein, respectively, $p<0.001$ ) (Fig. 6).

The RAR-specific binding in the reference maternal rat lung was $7042 \pm 772 \mathrm{dpm} / \mathrm{mg}$ protein $(n=6)$ compared with 4932 $\pm 425 \mathrm{dpm} / \mathrm{mg}$ protein $(n=5)$ in rats raised on a vitamin Adeficient diet $(p=0.051)$. A separate experiment was done in which weanling rats were raised on a deficient diet and given daily supplemental vitamin A (100 retinol equivalents/d). In these adult animals, although none were successfully mated, the liver RP concentration was in the high normal range $(1590 \mathrm{nmol}$ $\mathrm{RP} / \mathrm{g}$ liver) and the lung RAR-specific binding (5948 \pm 889 $\mathrm{dpm} / \mathrm{mg}$ protein, $n=5$ ) was similar to, but not statistically different from, that in the reference and deficient groups.

\section{DISCUSSION}

Vitamin A is known to be an important factor in lung growth and maturation, and recently interest has turned to the nuclear RAR as possible regulators of retinoid function $(13,14) \mathrm{Al}$ though many studies have focused on adult animals or human malignant cell lines, little has been done to investigate RAR in developing tissues. The purpose of this study was to examine the effect of gestational age and vitamin A deficiency on fetal rat lung RAR. In agreement with previous findings in HL-60 cells (15), a single class of receptor sites with a high affinity $\left(\mathrm{k}_{\mathrm{d}} \sim 10^{-9}\right.$ M) for RA and an approximate molecular mass of $50 \mathrm{kD}$ was identified in fetal lung nuclear extracts. The assay was reproducible with a variation of less than $10 \%$ and demonstrated a doseresponse relationship with nuclear protein concentration. Endog- 
Table 1. Characteristics of control and vitamin A-deficient pregnancies*

\begin{tabular}{|c|c|c|c|c|c|}
\hline Group & $\begin{array}{c}\text { No. of } \\
\text { pregnancies }\end{array}$ & $\begin{array}{c}\text { No. of fetuses } \\
\text { per litter }\end{array}$ & $\begin{array}{l}\text { Avg. fetal } \\
\text { weight }(\mathrm{g})\end{array}$ & $\begin{array}{c}\text { Maternal } \\
\text { liver } \mathrm{RP}(\mathrm{nmol} / \mathrm{g})\end{array}$ & $\begin{array}{c}\text { Fetal liver } \\
\text { RP (nmol/g) }\end{array}$ \\
\hline Control & 7 & $11.8 \pm 0.8$ & $4.62 \pm 0.33$ & $866 \pm 224$ & $33.8 \pm 1.4$ \\
\hline Deficient & 5 & $4.2 \pm 1.0 \dagger$ & $3.15 \pm 0.37+$ & $46 \pm 12$ & $13.2 \pm 2.7 \dagger$ \\
\hline
\end{tabular}

$*$ Values are mean \pm SEM.

$\dagger p<0.001$.

$\ddagger p<0.02$.

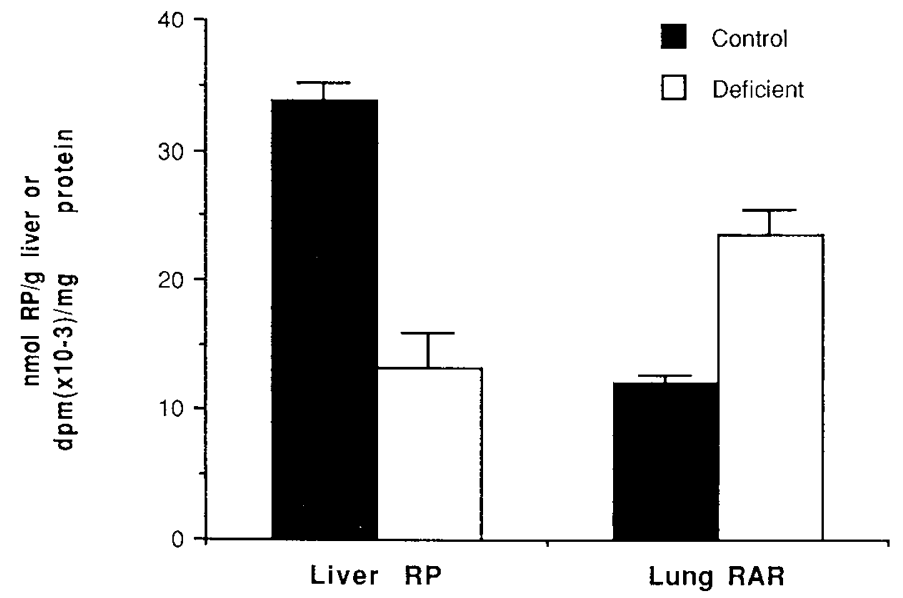

Fig. 6. Fetal liver RP concentration and lung RAR-specific binding. Liver RP concentration was measured by HPLC analysis in control and vitamin A-deficient $(\square)$ fetuses. The lung RAR-specific binding of these fetuses was determined using the method described in the text.

enous RA was unlikely to be a factor in this assay because neither incubation at room temperature nor incubation for extended periods of time affected the results. In addition, nuclei preparation was carried out in the presence of normal overhead lighting, which is known to rapidly degrade RA, and RA was not detected in nuclear extracts (limits of detection were less than $20 \%$ of exogenous radiolabeled RA used for the assay).

Lungs from rat fetuses delivered prematurely at $18 \mathrm{~d}$ gestation had two to three times as much RAR-specific binding as lungs from older fetuses, newborns, or adults. Specific binding is determined by both the affinity of a ligand for its receptor and the total number of receptor binding sites. Equilibrium $k_{d}$ are one measure of receptor affinity. In this study, the derived $k_{d}$ for the earlier gestational ages was slightly higher than for later in gestation. A higher $\mathrm{k}_{\mathrm{d}}$ indicates a ligand-receptor complex with lower affinity, which would manifest as lower specific binding. Because RAR-specific binding was higher in rat fetuses of younger gestational age in this study, this observation is unlikely to be a result of differences in receptor affinity. From this it would appear that 18 -d fetal rat lung has two to three times as many RAR binding sites as older animals. The primary purpose of the Scatchard plot was to demonstrate the existence of a specific and single RAR binding site, and this was shown by the linear relationship. However, it is unclear whether the differences in the $k_{d}$ are significant or whether these values reflect variation about the mean. Similarly, although the intercepts on the abscissa do not reflect a 2- to 3-fold difference in number of binding sites under maximal binding conditions, there is a trend for the 18and 19-d gestations to have larger intercept values than the 20and 21-d gestations. This further supports the conclusion of a larger receptor number at earlier gestational ages. Additional work is needed to more completely characterize the fetal rat lung RAR and to resolve these questions.

Western blot analysis demonstrated at least $\beta$ - and possibly some $\alpha$-receptor in fetal rat lung. Use of these particular antibodies does not always demonstrate the $\gamma$-receptor, and the larger $\alpha$ $(\sim 60 \mathrm{kD})$ is frequently seen (Chambon P, personal communication). The primary purpose of the Western blot analysis here was to show that the HPLC fractions isolated reacted with RAR antibody. Further studies using Western blot analysis to quantitate changes in RAR content during advancing gestation and in states of vitamin A deficiency are needed. The expression of RAR in early embryo and adult lung has been previously shown $(16,17,22)$.

Liver RP was chosen as the marker for vitamin A deficiency because it represents the major storage form of vitamin A. Litter size and average fetal weight obtained from pregnancies of vitamin A-deficient rats were smaller than those in control pregnancies as previously reported by Takahashi et al. (23). Liver RP concentration of the experimental fetuses was statistically lower than that of controls, yet lung RAR-specific binding was nearly doubled. The reason for this increased receptor number is unclear. One explanation might be that it reflects a period of rapid growth with a higher protein content of the whole animal; however, standardizing for amount of protein in the assay as was done in this study should correct for this. Alternatively, it is known that in 18-d rat fetal lung RP storage is high and decreases rapidly with birth, whereas retinol remains at a steady low level (24). At early gestations then, perhaps the observed up-regulation of the RAR is an adaptive measure to a predominate storage pathway that supplies little RA. As birth approaches, more ester is converted to metabolically active RA and so there is less need to have higher concentrations of RAR.

Adult lung RAR-specific binding was slightly diminished with vitamin A deficiency. This is consistent with the results of others $(22,25)$ who report a decrease in mRNA levels of lung RAR- $\beta$ in retinol-deficient rats compared with controls. Generally in studies of RAR expression in adult animal tissue, RA induces the RAR- $\beta$ gene $(13,14,17)$. The observation here of an apparent increase in the total RAR protein-specific binding in vitamin Adeficient fetal rat lung requires further study for an explanation. Perhaps this represents less degradation of the RAR in an effort to conserve receptor number in the presence of deficiency. It is known that in mild vitamin A deficiency in adults, some organs such as kidney and lung actually have higher concentrations of retinol than in the normal state. If that has occurred in these vitamin A-deficient fetuses, perhaps the up-regulation of lung RAR was actually associated with higher lung retinol than in control fetal lung. Although retinol and RP concentrations in lungs of deficient adults consuming this diet are lower than in controls (25), the fetal lung vitamin $\mathrm{A}$ in the five deficient pregnancies studied here was not analyzed. Additional research will be required to clarify this issue.

In summary, the observations reported here suggest that both gestational age and vitamin A are important regulators of RAR in developing lung. Such regulation might be important as well in the pathogenesis and/or repair of neonatal lung injury.

Acknowledgment. The authors thank Dr. Ajit K. Verma, Department of Human Oncology, for his assistance in the Western Blot procedure reported here and Dr. Robert H. Lustig, Department of Pediatrics, for assistance in the Scatchard analysis. The gift of the polyclonal antibodies to RAR $-\alpha,-\beta$, and $-\gamma$ from Dr. Pierre Chambon, Paris, is gratefully acknowledged.

\section{REFERENCES}

1. Blackfan KD, Wolbach SB 1933 Vitamin A deficiency in infants. A clinical and pathological study. J Pediatr 3:679-706 
2. Harris CC Sporn MB, Kaufman DG, Smith JM, Jackson FE, Saffiotti U 1972 Histogenesis of squamous metaplasia in hamster tracheal epithelium caused by vitamin A deficiency or benzopyrene ferric oxide. Natl Cancer Inst 48:743-761

3. Boren HG, Pauley J, Wright EC, Kaufman DG, Smith JM, Harris CC 1974 Cell populations in the hamster tracheal epithelium in relation to vitamin $\mathrm{A}$ status. Int J Vitam Nutr Res 44:382-390

4. Northway WH, Rosan RC, Porter DY 1967 Pulmonary disease following respiratory therapy of hyaline-membrane disease-bronchopulmonary dysplasia. N Engl J Med 276:357-368

5. Brandt RB, Mueller DG, Schroeder JR, Guyer KE, Kirkpatrick BV, Hutcher NE, Ehrlich FE 1978 Serum vitamin A in premature and term neonates. J Pediatr 92:101-104

6. Shenai JP, Chytil F, Jhaveri A, Stahlman MT 1981 Plasma vitamin A and retinol-binding protein in premature and term neonates. J Pediatr 99:302305

7. Shenai JP, Chytil F, Stahlman MT 1985 Liver vitamin A reserves of very-lowbirth-weight neonates. Pediatr Res 19:892-893

8. Hustead VA, Gutcher GR, Anderson SA, Zachman RD 1984 Relationship of vitamin A (retinol) status on lung disease in the preterm infant. J Pediatr 105:610-615

9. Shenai JP, Chytil F, Stahlman MT 1985 Vitamin A status of neonates with bronchopulmonary dysplasia. Pediatr Res 19:185-188

10. Shenai JP, Kennedy KA, Chytil F, Stahlman MT 1987 Clinical trial of vitamin A supplementation in infants susceptible to bronchopulmonary dysplasia. $\mathrm{J}$ Pediatr 3:269-277

11. Pearson E, Bose C, Snidow T, Ransom L, Young T, Bose G, Stilles A 1992 Trial of vitamin A supplementation in very low birth weight infants at risk for bronchopulmonary dysplasia. J Pediatr 121:420-427

12. Blomhoff R, Green MH, Berg T, Norum KR 1990 Transport and storage of vitamin A. Science 250:399-404
13. Wolf $G 1991$ The intracellular vitamin A binding proteins: an overview of their functions. Nutr Rev 49:1-11

14. Lotan R, Clifford JL 1991 Nuclear receptors for retinoids: mediators of retinoid effects on normal and malignant cells. Biomed Pharmacother 45:145-156

15. Nervi C, Grippo JF, Sherman MI, George MD, Jetten AM 1989 Identification and characterization of nuclear retinoic acid-binding activity in human myeloblastic leukemia HL-60 cells. Proc Natl Acad Sci USA 86:5854-5859

16. Dolle P, Ruberte E, LeRoy P, Moviss-Kay G, Chambon P 1990 Retinoic acid receptors and cellular retinoid binding proteins 1 . A systematic study of their differential pattern of transcription during mouse organogenesis. Development 110:1133-1151

17. Chytil F 1992 The lungs and vitamin A. Am J Physiol 262:L517-L527

18. Lowry OH, Rosebrough NJ, Farr AL, Randall RJ 1951 Protein measurement with Folin phenol reagent. J Biol Chem 193:265-275

19. Wallingford JC, Underwood BA 1987 Vitamin A status needed to maintain vitamin $A$ concentrations in nonhepatic tissues of the pregnant rat. $J$ Nutr 117:1410-1415

20. Grummer MA, Zachman RD 1990 The effect of maternal ethanol ingestion on fetal vitamin A in the rat. Pediatr Res 28:186-189

21. Scatchard G 1949 The attraction of proteins for small molecules and ions. Ann NY Acad Sci 51:660-681

22. Haq R, Pfahl M, Chytil F 1991 Retinoic acid affects the expression of nuclear retinoic acid receptors in tissues of retinol-deficient rats. Proc Natl Acad USA 88:8272-8276

23. Takahashi YI, Smith JE, Winick M, Goodman DS 1975 Vitamin A deficiency and fetal growth and development in the rat. J Nutr 105:1299-1310

24. Zachman RD, Kakkad B, Chytil F 1984 Perinatal rat lung retinol (vitamin A) and retinyl palmitate. Pediatr Res 18:1297-1299

25. Verma AK, Shoemaker A, Simsiman R, Zachman RD 1992 Expression of retinoic acid nuclear receptors and tissue transglutamine in various tissues of rats fed a vitamin A deficient diet. J Nutr 122:2144-2152 